\title{
In Stemoriam
}

\author{
LAVAL LAURENT, O.F.M.
}

$1914-1944$

HE ACADEMY OF AMERICAN FRANCISCAN HISTORY
has lost one of its Associates, and The Americas one of its Editors in the sudden death of Father Laval Laurent, O.F.M., S.T.D., which occurred at Saint-Ligouri de Montcalm, in the Province of Quebec, Canada, on June 29, 1944.

By his death the Canadian Franciscan Province of St. Joseph has lost a zealous young priest and promising young scholar in the field of Canadian and Franciscan History.

Born at Quebec, June 3, 1914, Father Laval completed his courses in Letters and Philosophy at the Petit Seminaire of Quebec in June of 1934. He entered the Franciscan Novitiate at Sherbrooke, where he made his religious profession on August 15, 1936. After the regular theological studies, he was ordained to the priesthood June 29, 1940. His first appointment was to the editorial staff of Culture, the well-known Canadian quarterly review published at Montreal. In order to develop his evident talents for research and writing, Father Laval matriculated at The Catholic University of America, Washington, D. C., in the fall of 1942. Here he specialized in American Church History, under Msgr. Peter Guilday, dean of American Church historians, and obtained his Doctorate summa cum laude, on last May 17th.

His doctoral dissertation entitled: "Les relations de Mgr. Plessis et de Mgr. Briand avec l'Église américaine," based on manuscript material discovered by Father Laval in the principal libraries and archives of the United States and Canada, won considerable notice and high commendation.

Fr. Laval devoted his vacation to work at a Camp for underprivileged children of Montreal. His death was caused by a heart attack which struck him while he was testing the safety of a swimming place for a group of children in his charge. It was the fourth anniversary of his ordination, almost to the very hour. $\mathrm{He}$ was thirty years of age. The funeral was held at the Franciscan church 
in Montreal. The Academy of American Franciscan History was represented by the Rev. Dr. Archange Godbout, O.F.M., Corresponding Member, and The Catholic University of America by Msgr. Guilday, Honorary President of the American Catholic Historical Association.

At the time of his death Father Laval was preparing for the Academy of American Franciscan History studies based on archival sources concerning Fr. François Louis Chartier de Lotbinière, O.F.M., the first chaplain of the U. S. Army during the Revolution, and Fr. Simple Boquet, O.F.M., missionary at Detroit, and other Franciscan chaplains of the French forts of the Great Lakes and the Mississippi Valley.

Besides his thesis, which is now in press, and which is anxiously awaited, Fr. Laval had written a bibliography of the Papal Encyclical "Rerum Novarum" in collaboration with his brother Eduoard, a popular translation of the Epistle of St. James, and many articles published in Nos Cabiers, Culture, and "Survey of Church History in Canada in 1943," in the first number of The Americas (July, 1944).

His death is mourned by all who knew him as a loyal confrère, a priest of profound though unostentatious piety, a thorough and careful student of keen intelligence and with remarkable gifts for historical research, with an already extensive knowledge of the source materials for the history of Canada and of the Franciscan Order in the Americas. He possessed to a high degree the "grace of working" which St. Francis desired for his friars.

Requiescat in pace! 